\title{
The Symbolic Meaning of Song Lyrics and Choreographic Form of the Tombulunese Three-Stage Maengket Dance
}

\author{
Sri Sunarmi, Grace Shirley Luntungan
}

\begin{abstract}
This research has an inventory of works of local arts whilst expressing the symbolic meaning of song lyrics and the choreographic form of the three-stage Tombulunese dance.

Phenomenology, Ethno Art, Hermeneutics and Symbolics are used to understand phenomena which fundamental ways of continuous experience are. This approach can see and reveal two answers to the purpose of this study. The song lyrics shows messages in the form of advice, invitations, to always give thanks to God for the blessings that have been given to His people. When starting an activity, always ask for His protection. It also gives the message that in people's lives in general, humans always need communication between people. Humans as living beings need to relate to each other. Especially for the next generation, it is expected that the relationship between men and women will continue to domestic life. The choreography of the Maengket dance is a form of social intercourse, which is carried out by young couples in groups. This presentation is carried out in a combination of motion, singing, literature and is accompanied by a drum instrument. The presentation consists of three rounds which are the themes and are presented as well as one form of presentation in sequence. The Maengket dance is a rite that has its symbols as a message, the appearance of the three circles of human life, namely food, board and breeding. It contains two things in its communication - vertically and horizontally and is associated with religion reflecting the institutional system of worship to the "Upper World".
\end{abstract}

Keywords: Symbolic meaning; song lyric; choreographic form; maengket dance.

\section{INTRODUCTION}

Tombulu is one of the sub-ethnic groups of the Minahasa people who inhabit the area of Tomohon City and Tombulu Sub-district in the North Sulawesi province. Minahasa also has a culture that is different from other ethnic regions or tribes. Culture of religion, behavior and culture of art is also different from other regional cultures. A form of art in the Minahasa ethnic group is the Maengket Dance. But lately concern about the understanding of the Maengket Dance in Minahasa is understandable.

Solicitudes from various parties regarding the loss of the "pride" of the country's children towards ritual events in

Revised Manuscript Received on September 22, 2019.

Sri Sunarmi, Faculty of Language and Arts,Manado State University, UNIMA Campus in Tondano, Minahasa 95618, Indonesia. srisunarmi@unima.ac.id.

Grace Shirley Luntungan, Faculty of Language and Arts,Manado State University, UNIMA Campus in Tondano, Minahasa 95618, Indonesia. graceluntungan@unima.ac.id.
Minahasa was enough to provide a reason for this issue to be observed. This statement causes concern towards the tradition that the Minahasa people attempt to uphold. Superstructure is more likely to refer to thoughts that include ideology, religion and/or belief, science, art and literature (Sanderson, 1995: 62)

Based on these thoughts, one can be assured that the Maengket dance contains many symbolic meanings in song poetry and choreographic forms.

\section{LITERATURE REVIEW}

\section{A. Definition of Maengket Dance}

The Maengket dance is a ritual event emphasizing its expression in body movements utilizing rhythm and attempts to harmonize volume and perspective. The dance is a ritual event delivered in large crowds using white clothes and must begin with someone exclaiming 'tumutuur' and then followed by others.

Maengket as a ceremonial dance activity with the aim of illuminating, paving the way and uniting the community in the situation of rice harvesting activities in Minahasa called maoweykamberu. The ceremony takes the form of a new house, which is culturally called maramba. In the ceremony a portion of the ritual is given that allows the establishment of an atmosphere of youth association in Minahasa called lalayaan (Pangkey et al, 1986: 78). For this reason, in the presentation of the Maengket dance, it always consists of three rounds, namely the makamberu round, the maramba round, and lalayaan round. The three rounds are displayed at once and become one form of presentation performed in sequence. The young couples are paired together with a 'lenso' (handkerchief) which is moved in accordance to the rhythm. Moving while singing songs that are accompanied by a musical instrument drum. The leader in Maengket is called the kapel and manages each change in motion patterns, floor patterns, poems and songs from one round to the next. The dancer moves according to the literary meaning and content of the music. Moves on the feet more movement with small steps and tiptoes which are stomped (jinjit-jinjit) on the floor. In connection with music, there is a vocal sound with accompaniment instrument which is called a tambor. 
The number of tambor can be one to three. In terms of vowels, in the presentation of Maengket one voice often sounds, two sounds and three sounds, and sung solo, trio and choir or together. Depending on the message of the lyrics, the atmosphere changes.

\section{B. Elements of the Maengket Dance}

\section{1) Motion Pattern}

Motion pattern used in Maengket dance is very simple movements. The movement used is more dominant in hand movements than foot movements. The motion in Maengket dance also uses the motion that is mbanyu mili, which is a movement that can be assumed as the motion of flowing water (Sunarmi, 2004; 79). However, there is a slight tempo given the pressure to clarify the purpose of the movement.

\section{2) Floor Pattern}

Basically, the understanding of floor patterns in dance is lines on the floor that are formed or shaped by certain formations. Patterns are used to present a particular movement, or trajectories that the dancer traverses when moving places or positions to make a formation in presenting a certain movement to form a certain line as well. There is a formation where the dancers while singing in a row then form a circle formation. Next change into a semicircular formation, and sometimes formations such as the letter "V" also like the letter "U". Other formations that often exist are formations lined up "jajar" one facing front parallel, and marching "jajar" two facing the front parallel. Then, line one in two rows, stand on the right and left side of the kapel.

\section{3) Poem}

The poem on Maengket Dance is very important, because the poem determines the singing and movement of the dancers. The poem in Maengket is a literature determines the content and meaning of the round of tababak that is on Maengket. In this case it is the object of study, used tombulu language literary poetry, Titus P. Loho's composition. as found in the Dewa Ruci journal of study and art creation, and the verses are as follows:

\section{a) Makamberu $1^{\text {st }}$ Round Poem}

Sigi'wangko' naipelengewia se tu a wokatuari e, Iyayonaimomapelengesigi' wangko' kenuwiamo, Opowananatase,Tembonome, tembonome kai e, I mengalei, kai I mengaleye, kamangwangko.

All our respect and praise is presented to the audience, this is our offering all at the moment,

O Lord in the most high place. Look at us, Look at our hearts,

we beg for Your blessings, we who beg for Your abundant gift, thanks to Your great gift.

\section{b) Maramba's Second Round Poem}

Sisigi-an e makawale,

kai wiamo e makawale,

semakapetor,Hoi,E makawalesanawia-wiamonikai e makawale,

tanumountarendemtinalinganaimemakawale. respect to the host, right now we are here, a leader invites guests to stand up and plead with God, hi, our host all we've been here at home,

\section{c) Lalayaan $3^{\text {rd }}$ Round Poem}

Lumaya tare kitakaria, aku ma' wa' tumarendemkaria, imbiangkanpere-geregesankaria, akuwomakawawakankaria

let's dance dear, I try to convey my heart's intentions dear, in a place where the breeze blows dear, can I have you dear.

\section{4) Fashion}

Clothing worn by Maengket dancers basically uses uniform "uniform", tends to use the same shape, model, and color. The clothes used by the dancers for the performance of Maengket were divided into two parts, including: headwear and clothing.

\section{5) Property}

Property is a tool used by dancers on stage or stage, which is used to clarify the theme and purpose to be conveyed. The property used in Maengket dance was using a lenso or handkerchief. Lenso is made of fabric, usually the color used is white or red in a square with a size of $30 \mathrm{~cm}$.

\section{6) Music}

Music in Maengket dance is different from music in other dances. Maengket dance uses certain instruments and vowels that are using the sound of a singing dancer accompanied by percussion instruments, namely a tambor. A tambor is a large drum-shaped instrument shaped like a drum-band that is played using sticks or beaters like people play drum-bands too. The sound of tambor who was present and heard inside Maengket tended to be simple, because it only offered two colors that sounded like "dung" and "dang" only.

\section{Concept Symbol}

The meanings of the symbols contained in the structure of Maengket dance need to be maintained because of the cultural values of the people in Minahasa. To reveal the symbolic meanings of several elements found in the structure of Maengket dance performances in the context of the application ceremony, some symbolic concepts are also used. According to Munro, the symbols are divided into three of them:

- Symbols or signs as symptoms of signs received by the five senses, can be either movements or sounds or sounds.

- Signs in the form of images, objects that have primary and secondary meanings, are also called polysemous interpretations through a parable. Suppose the sign is conveyed by expressions in literary poetry, poetry, etc.

- Symbols are symbols that exist in two or more metaphysical levels called symbolism or symbolism to interpret things that are not visible (1969: 59). 
- Symbols hold a cultural significance and has the ability to express deeper meanings. (Berger, 2000: 23-24).

\section{Methodology/Materials}

The research methods applied needs to be explained in formulation of the problem. The first question is answered by descriptive choreographic explanation, while the second question is answered with an explanation based on interpretative analysis with its characteristic that is typically reflective and philosophical. In answering the second question in this study answered by living reflective thoughts on the values believed by the Minahasa community through Maengket dance.

The stage of data collection is an activity related to the search for data that the author does through various methods including library research, observation, interviews, and recording.

\section{RESUlts AND FINDINGS}

The Meaning of Symbolic Poetry of the Song and the Choreographical Form of the Maengket Dance. Awareness in the realization of life, a symbol is required so that people are able to be united with their Creator, nature, and others. As stated by Herusatoto, "Every cultural object or work of art marks a certain value and shows the intentions and ideas of its creator" (Herusatoto, 1983: 9).

Therefore, dance itself has meaning based on each value that can be understood by society in general. According to Husserl, Phenomenology gives attention to problems that contain intentions and is directed at the world of life that is built by subjects who interact, communication.

In this case, the Maengket Dance functions as a rite medium which is religious symbols that reveal two things, namely revealing the relationship between the individual and the Divine in obtaining the meaning of his life that expresses about farming, settlement between male and female social relations (Turang, 1997: 19). Hermeneutics is an effort to understand and interpret a text, feelings and meaning of an event. Symbols are an indication or symptom that can be captured by the five senses. A symbol is a representation that has a primary and secondary meaning that pays attention to the interpretation of the parable. The aspects presented by the cast include title, dancer, theme, conception, poetry / literature, motion patterns, shape of the floor pattern, and property in Maengket dance.

\section{A. Title}

The interpretation in the title is a symbol that reflects the message as a concept of thought in the Minahasa community. The message conveyed is an example in a wurukan or invitation to introduce, as well as by instilling together values.

\section{B. Dancer}

The aspect of dancers in Maengket dance is very important because in dancers as actors certainly have symbols as the meaning of the concept of thought of the supporting community.

Based on the object in Maengket dance, male and female couples can be interpreted as a symbol in life. But more importantly, male and female dancers, according to the concept of Munro (1969: 59), these symbols exist in two or more metaphysical levels called symbolism to interpret things that are not visible. Maengket dancers who are not as kapels or ordinary dancers can be interpreted as symbols that reflect groups or communities. Dancers who serve as kapels can be interpreted as a symbol of the reflection of one of the elder community members to lead.

\section{Theme}

Like folk dance and social dance in general, Maengket does not have a theme such as a dance patterned story. In order to convey the message, individuals tend to present themselves accompanied with artistic concepts to demonstrate unity amidst the hardships of life. The theme of unity and mutual cooperation amongst the people (Mapalus) is limited to activities in opening gardens, hoeing fields, sowing \& reaping of rice, and in cooperation in house construction.

\section{Conception}

The distribution of the Maengket Dance directs us to understanding, status and quality of how life reaches "the divine spirit." Because the three rounds contain themes and meanings of expressing gratitude to God Almighty, because of their success in building social solidarity in a togetherness. a theme that reflects an invitation in solidarity to always remember the Almighty God, before and after an activity.

\section{E. Poem}

The poetry in Maengket dance is very much determined by the literature that speaks the Minahasa region. Poetry, which is a literature found in each chapter of the dance has its own meaning. Poetry in the first half is kamamberu. Based on the term Makamberu it can be interpreted that the origin of the term is from "Mahowey and Mahkaberu", which is used to replace the name of the understanding of the rice harvest season. The use of the words "mah" and "ma" is the same. The word "ma", in this case can be interpreted as a collection or group or season. Whereas the word "mah" means temporary or carrying out. Actually the word "Owey" is a statement of shock, and a sense of wonder. Kamberu, can also be interpreted as the rice harvest season.

Song lyrics can be interpreted to convey and replicate lines from the couplets. The message conveyed is advice, invitation, to always remember the Divine. As a creature God must oblige Him. Because as the Almighty who has created everything that is on earth, it is obligatory to give thanks for the blessings and blessings that have been given to His people. Syair in the Maramba round, which is a type of art that applies to all types of party entertainment. The poetry in the maramba round can be interpreted to reflect a message, but be cautious as it has an alternate meaning to 
challenge the power of a household.

The movements in the Maengket dance utilizes simple gestures - prominently focusing on hand movements rather than foot movements. In the dance, it uses a motion called mbanyu mili as well as particular movements that are adjusted to the purpose and content of the themes and poems that are on it. Based on the particular movement, it can reflect the community's relationship with God and other human beings.

Based on the concept, the movements reflect the symbol of the Minahasa community both vertically and horizontally. Vertically, it appears once in the vocabular motion of both hands which lifts the hand above the pleading sign and the expression of gratitude as seen in the Mangaley vocabular. Horizontally it appears on the vocabular movements of the implantation, arm in motion, motion with the hand placed on the shoulder, and following the commands of the kapel, and so on, this is apparent in the vowels of Mahtondongan and Mahpurengkey.

\section{F. Floor pattern}

Based on the patterns or formations that exist on Maengket can be interpreted as something that is held, of course there are meanings and symbols that become messages to be conveyed. The kapel position is always in the midst of all dancers. In principle, the existing floor patterns can be interpreted so that they can show certain symbols. The symbols on the floor pattern are a reflection of the community in its communication vertically and horizontally. The symbol of togetherness and mutual cooperation which is the meaning of Maengket dance can be seen in all formations but is prominent in the circle and semicircle formation. In accordance with the concept of Munro, the pattern of the circle floor can reflect or symbolize that God is something transcendental and permanent means that God does exist but not visible (1969: 59).

\section{G. Property}

Property is a tool used by dancers on stage to clarify the theme and purpose to be conveyed. Property in Maengket uses a lenso. Lenso is made of fabric, usually the color used is white, square with a size of $30 \mathrm{~cm}$. Symbolic concept according to Munro (1969: 59) that a symbol is a sign in the form of an image, an object that has primary and secondary meanings, also called polysemous, whose interpretation is through a parable.

\section{Conclusion}

Based on the previous descriptions, it can be concluded that Maengket dance is a form of art or work that is indirectly used as a means for developing the culture of local communities in relation to the cultural system itself.

The elements are very simple but contained the messages conveyed. Maengket dance is the appearance of three circles of everyday human life, which contain two things in their communication vertically and horizontally. Maengket dance contains the religious dimension, namely the dimension relating to or manifestation of the recognition of "the Peak
Faith" of life. Its existence appears to live from generation to generation, from generation to generation. Maengket dance developed into an art form that represents the cultural characteristics of the Minahasa community.

\section{REFERENCES}

[1] Berger, Arthur Asa. 2000. Tanda-tanda dalam Kebudayaan Kontemporer. Yogyakarta : PT. Tiara Wacana.

[2] Herusatoto, Budiono. 2000. Simbolisme Dalam Budaya Jawa. Yogyakarta: PT. Hanindita Graha Widia.

[3] Munro, Thomas, 1969. The Art and Their Interrelations. London: The pres of case Western Reserve University Cleveland and London.

[4] Pangkey, J.A. 1986. Peralatan Hiburan Dan Kesenian Tradisional Daerah Sulawesi Utara.Sulawesi Utara: Depdikbud Direktorat Jenderal Kebudayaan Direktorat Sejarah Dan Nilai Tradisional Proyek Inventarisasi dan Dokumentasi Kebudayaan Daerah.

[5] Sunarmi, Sri. 2004 .Tari Maengket : "Perspektif Pemikiran Di balik Ritual Pergaulan di Minahasa”. Dewa Ruci, Jurnal Pengkajian \& Penciptaan Seni. Program Pendidikan Pascasarjana STSI Surakarta, Vol. 2, No.2, April 2004.

[6] Turang, J. 1997. Profil Kebudayaan Manusia. Tomohon: Majelis Kebudayaan Minahasa.

\section{AUTHORS PROFILE}

Sri Sunarmi, I am affiliated with Faculty of Language and Arts,Manado State University, UNIMA Campus in Tondano, Minahasa 95618, Indonesia.my area of interest is social sciences

My name is Grace Shirley Luntungan, I am from Faculty of Language and Arts,Manado State University, UNIMA Campus in Tondano, Minahasa 95618, Indonesia.my area of interest is social sciences 